\title{
Effect of Health Education Video on Knowledge about Stunting among Women in Childbearing Age
}

\author{
Annisa Nuraini, ${ }^{1}$ Puspa Sari, ${ }^{2}$ Sri Astuti, ${ }^{2}$ Lani Gumilang, ${ }^{2}$ Didah $^{2}$ \\ ${ }^{1}$ Midwifery Study Program Faculty of Medicine Universitas Padajadjaran, Indonesia, \\ ${ }^{2}$ Department of Public Health Faculty of Medicine Universitas Padjadjaran, Indonesia
}

\section{Abstract}

Background: Toddlers aged 24-59 months are experiencing a very rapid growth process; however, they are also prone to have nutritional problems, including stunting. Stunting occurs mainly within the first 2 to 5 years of life. The main cause is a lack of knowledge on toddler's nutritional intake among women of childbearing age. This study aimed to explore the effect of health education using video media on the knowledge about stunting among women of childbearing age.

Methods: This was a quantitative, experimental study with one group pretest-posttest design conducted in July-November 2019 on women of childbearing age in the working area of Public Health Center (Pusat Kesehatan Masyarakat, Puskesmas) Jatinangor, West Java, Indonesia. Respondents were recruited using the Multistage Random Sampling according to the inclusion criteria. A pre-test was administered before the health education session on stunting and a post-test was administered afterwards. Data collected were then analyzed using the Wilcoxon Test.

Results: In total, 211 women were included. Education video on stunting was proved to significantly increase the respondent's knowledge on stunting $(\mathrm{p}=0.000$, $\mathrm{r}$ value $=0.690)$.

Conclusions: Health education video clearly increases knowledge on stunting among women of childbearing age. Thus, video medium can be used as a preferred method for disseminating knowledge on various health topics.

Keywords: Childbearing age, knowledge, stunting, video, women

\section{Introduction}

Good nutrition is essential for optimal brain development and physical growth. Therefore, the nutritional intake needs to be arranged as early as possible; particularly in the first 1000 days of life, known as the golden growth period in human life. If the nutritional demand is not fulfilled, the growth and development of the children will be hindered. ${ }^{1}$ Toddler aged 24-59 months are experiencing a very rapid growth process, hence, they are easy to get malnutrition. ${ }^{2}$ One of the nutritional deficiencies experienced by toddlers is stunting. There are many factors that cause stunting, such as maternal malnutrition. In addition, inadequate infant and young child feeding (IYCF) can also cause stunting. ${ }^{3}$ Toddler with a nutritional status value of length/height below -2SD is designated as stunted, whereas severely stunted if the nutritional status value is below -3SD. ${ }^{4}$ Linear growth disorders or stunting is occurred mainly within 2-5 years, as the side effects of lack of nutritional intake. ${ }^{2}$

The Global Nutrition Report 2014 has shown that Indonesia is among 17 countries out of 117 countries with three nutritional problems, which are stunting, wasting, and overweight in toddlers. ${ }^{5}$ The National Health Research data has reported in 2018 that the prevalence of stunting $(30.8 \%)$ is higher than other nutritional problems such as malnutrition $(17.7 \%)$, underweight $(10.2 \%)$, and obesity $(8 \%)^{6,7}$ West Java has a similar prevalence of stunting $(29.2 \%)^{8,9}$ Based on data from the National Team for the Acceleration of Poverty

Correspondence: Annisa Nuraini, Midwifery Study Program, Faculty of Medicine Universitas Padjadjaran, Jalan Raya Bandung Sumedang KM 21, Jatinangor, Sumedang Indonesia, E-mail: annisaaaanuraini@gmail.com 
Reduction (TNP2K) in 2017, the prevalence of stunting in Sumedang Regency has reached $41.08 \%$, while in Jatinangor District the number of stunted toddlers is $19.23 \%{ }^{9}$

Stunting is influenced by several factors, such as maternal factors, hygiene and sanitation, a clean and healthy lifestyle, nonoptimal nutritional intake, no breastfeeding, and infection. ${ }^{3}$ In addition, lack of knowledge can be one of the causes of stunting. Furthermore, a lack of knowledge can occur among women of childbearing age. Most of them think that stunting is not a big problem and they do not know the future implication of stunting. Moreover, they do not understand the nutritional needs which should be fulfilled during the first 1000 days of life. ${ }^{3}$ Therefore, it is important to know the impacts and efforts to prevent stunting in order to reduce the high prevalence of stunting in Indonesia. One of the efforts to prevent stunting is health education. Health education can give motivation to individuals in applying the knowledge and behavioral changes. ${ }^{10,11}$ In addition, health education can be carried out with various media, such as video media as the most effective tools to deliver information. ${ }^{12,13}$

Fulfillment of nutrition in the first 1000 days of life is very important; especially to prevent stunting. Therefore, it is necessary to have a good understanding regarding the fulfillment of nutrition at the 1000 days of life. However, the knowledge of women of childbearing age regarding the importance of nutrition in the first 1000 days of life in Jatinangor is still low. They do not know about stunting, as the complication of less nutritional intake. ${ }^{4}$

Therefore, we were interested in providing health education; especially about stunting by using video. The aim of this study was to explore the effect of health education through video on the knowledge about stunting among women of childbearing age.

\section{Methods}

This research was an experimental study with one group pre and post-test design. The population in this study was women of childbearing age who lived in the working area of the Public Health Center Jatinagor. The area included 7 villages which were Cibeusi, Cipacing, Cikeruh, Sayang, Hegarmanah, Cileles, and Cilayung. The Public Health Center Jatinangor had reported that there were a total of 14,225 women of childbearing age in 2018. The Multistage Random Sampling technique was used in this study. The sampling process began with cluster sampling, then proportionated random sampling was applied to determine the proportionate number of samples per village and sample of each RW. After that, the simple random sampling technique was carried out. Sampling with simple random sampling was conducted by ordinal mode, by taking the names of women of childbearing age with odd numbers. The oddnumbered names of women of childbearing age were used as research samples. This study was conducted from July to November 2019. This study has been registered in the Research Ethics Committee Universitas Padjadjaran (No.1018/UN6.KEP/EC/2019).

There were 221 women of childbearing age who had met the inclusion criteria. The questionnaire used was taken from previous study (courtesy of Sri Astuti ${ }^{15}$ ) with the modification. The questionnaire had been tested for validity and reliability in Cisempur and the result of the test was valid and reliable. The questions in the pre-test and posttest questionnaires used closed questions in the form of true, false, and unknown statements. Before the research was carried out, respondents were given an informed consent sheet and signed in as an agreement to participate in the research. A questionnaire was given before and after a health education video about stunting. The video concept was created by the researcher and the video creation process was assisted by the video maker in the form of a moving animation video to make it more interesting to watch as well as to understand the material easier. The video content explained stunting, starting from the definition of stunting, the prevalence of stunting in Indonesia and West Java, the factors which cause stunting, the impact of stunting, efforts to prevent stunting, and the role of nutrition in preventing stunting. The duration of the video was 6 minutes 52 seconds. Respondents were required to watch the video from beginning to end so that the material would have been delivered properly. The references for stunting education in the video were obtained from WHO, the Indonesian Ministry of Health, and various journals. The video was further sent to the respondent through WhatsApp, and thus the respondents could re-watch the video. A posttest was carried out to measure respondent's knowledge about stunting 7 days after the education using the same questionnaire.

The data were analyzed using the Wilcoxon test to determine the effect of health education through video media on knowledge. 
Table 1 Knowledge about Stunting among Women of Childbearing Age

\begin{tabular}{lcccc}
\hline \multirow{2}{*}{ Knowledge } & \multicolumn{2}{c}{ Pre-Test } & \multicolumn{3}{c}{ Post-Test } \\
\cline { 2 - 5 } & $\mathbf{n}$ & $\mathbf{\%}$ & $\mathbf{n}$ & \% \\
\hline Good & 48 & 21.7 & 154 & 69.7 \\
Enough & 72 & 32.6 & 47 & 21.3 \\
Less & 101 & 45.7 & 20 & 9 \\
\hline
\end{tabular}

Table 2 Knowledge about Stunting among Women of Childbearing Age in Each Village in the Area of Public Health Center Jatinangor

\begin{tabular}{|c|c|c|c|c|c|}
\hline \multirow{2}{*}{ Village } & \multirow{2}{*}{ Knowledge } & \multicolumn{2}{|c|}{ Pre-Test } & \multicolumn{2}{|c|}{ Post-Test } \\
\hline & & $\mathbf{n}$ & $\%$ & $\mathbf{n}$ & $\%$ \\
\hline \multirow{4}{*}{ Cilayung } & Good & 1 & 6.3 & 7 & 43.8 \\
\hline & Enough & 3 & 18.8 & 7 & 43.8 \\
\hline & Less & 12 & $75^{*}$ & 2 & 12.5 \\
\hline & Total & 16 & 100 & 16 & 100 \\
\hline \multirow{4}{*}{ Cibeusi } & Good & 5 & 20.8 & 15 & 62.5 \\
\hline & Enough & 6 & 25 & 3 & 12.5 \\
\hline & Less & 13 & 54.2 & 6 & 25 \\
\hline & Total & 24 & 100 & 24 & 100 \\
\hline \multirow{4}{*}{ Cileles } & Good & 7 & 25.9 & 17 & 63 \\
\hline & Enough & 5 & 18.5 & 7 & 25.9 \\
\hline & Less & 15 & 55.6 & 3 & 11.1 \\
\hline & Total & 27 & 100 & 27 & 100 \\
\hline \multirow{4}{*}{ Cikeruh } & Good & 2 & 6.9 & 21 & 72.4 \\
\hline & Enough & 12 & 41.4 & 5 & 17.2 \\
\hline & Less & 15 & 51.7 & 3 & 10.3 \\
\hline & Total & 29 & 100 & 29 & 100 \\
\hline \multirow{4}{*}{ Sayang } & Good & 9 & 27.3 & 26 & 78.8 \\
\hline & Enough & 15 & 45.5 & 5 & 15.2 \\
\hline & Less & 9 & 27.3 & 2 & 6.1 \\
\hline & Total & 33 & 100 & 33 & 100 \\
\hline \multirow{4}{*}{ Hegarmanah } & Good & 13 & $32.5^{* *}$ & 29 & 72.5 \\
\hline & Enough & 11 & 27.5 & 9 & 22.5 \\
\hline & Less & 16 & 40 & 2 & 5 \\
\hline & Total & 40 & 100 & 40 & 100 \\
\hline \multirow{4}{*}{ Cipacing } & Good & 11 & 21.2 & 39 & 75 \\
\hline & Enough & 20 & 38.5 & 11 & 21.2 \\
\hline & Less & 21 & 40.4 & 2 & 3.8 \\
\hline & Total & 52 & 100 & 52 & 100 \\
\hline
\end{tabular}

Note: * the most 'less' knowledge and ** the most 'good' knowledge during the pre-test 
Table 3 Effect of Health Education through Video Media on the Knowledge about Stunting among Women of Childbearing Age

\begin{tabular}{lccccc}
\hline & Mean & S.d & Median & P- Value & R \\
\hline Pre-Test & 57.3 & 18.9 & 56.6 & 0.000 & 0.690 \\
Post-Test & 78.2 & 14.5 & 83.3 & & \\
\hline
\end{tabular}

Note: S.d = standard deviation

\section{Results}

Knowledge about stunting among women of childbearing age in the working area of Public Health Center Jatinangor was as followed; $45.7 \%$ had less knowledge in the pre-test, which was increased to good knowledge in 69.7\% (Table 1).

Women who had less knowledge were mostly (75\%) lived in Cilayung, those who had good knowledge were mostly (32.5\%) lived in Hegarmanah (Table 2). The knowledge before and after health education interventions through video media showed a significant increased ( $p=0.00$; Wilcoxon test) and a strong level of effect with a correlation value $(\mathrm{r}=0.690)$.

\section{Discussion}

Our study has shown an increase in the knowledge about stunting among women of childbearing age after health education through video media. Women living in Cilayung have less knowledge compared to those living in Hegarmanah who have more 'good' knowledge (Table 2). The distance of Cilayung is the farthest from the center of Jatinangor District compared to other villages, which is 4 kilometers away. ${ }^{16}$ Information acquisition about health is also influenced by the distance between places of residence to health services. ${ }^{17}$ Therefore, it is important to pay attention to the distance between the places of residence to the health service provider of information. Health services provide various health information, one of which is nutrition in toddlers. Therefore, the distance of residence to health services can affect knowledge. ${ }^{17}$

The knowledge about stunting, particularly among women of childbearing age, is very important. In addition, the level of knowledge of women of childbearing age about nutrition plays a role in nutritional problems in Indonesia, one of which is stunting. ${ }^{10}$ Therefore, it is very important for women of childbearing age to have good knowledge about stunting, including its effects and prevention efforts. The efforts to increase knowledge about stunting can be done through health education. Health education can motivate someone to apply the given knowledge, in this case, knowledge about stunting. ${ }^{11}$ Health education can be carried out by using various media, including visual, audio, and audiovisual media. In the study, audiovisual media videos were used. The content of the video is including the definition of stunting, the prevalence of stunting in West Java and Indonesia, the risk factor of stunting, the impact of stunting, and the role of nutrition in preventing stunting. The video used is in the form of a moving animation video to make the education more interesting and the conveyed message can be easily accepted by the audience. Education through video media is one of the media for learning methods aiming to improve cognitive and psychomotor abilities. Furthermore, it can influence attitudes and emotions since it uses various techniques and effects. ${ }^{18}$

Furthermore, there is a significant increase in knowledge after video education, showing that the effect of health education through video media is effective $(p=0.000)$. In addition, the level of influence of health education through video media has a strong level of influence with a correlation value of $\mathrm{r}=0.690$. Moreover, Health education through video media can increase knowledge and it can change the attitude. ${ }^{12}$ They can learn more information than the existing lecture method. ${ }^{19}$ Video media is one of the effective learning media in increasing knowledge. The "Cone Experience" theory by Edgar Dale classifies media based on learning experiences which are obtained starting from direct learning experiences, learning experiences that can be achieved through images and learning experiences that are abstract. If we prefer to experience learning process which more concrete and richer, we can use media that is around the base of the experience cone. For example, learning process experience, which is concrete, is the use of audio-visual media such as, video, since by using audio-visual media learners can more easily receive information provided. Dale predicts that the acquisition of learning outcomes is around 30\% through 
the sense of sight, while through the sense of hearing is $20 \%$. $^{19}$

Audiovisual media can increase knowledge. ${ }^{13}$ The benefits of using teaching or counseling materials which are presented in the form of a video of film make it easier for someone to learn on their own, can present a competitive situation, can be repeated, can display something in more detail, and can be accelerated or slowed down, so that it will be easier to absorb information. Therefore, the use of audiovisual media; such as video can make it easier for someone to absorb the information; besides, it can increase knowledge. Video media which is used as a learning method is considered more interesting and it is easier to understand its meaning. ${ }^{12,20}$

Limitations in this study are followed; we cannot confirm whether the respondent actually has watched the video at home after the pre-test until the next 7 days before the post-test has been carried out. We could only send reminders to the respondents every day to remind the respondents. The respondent may get bored with the same contents, therefore, different contents would be interesting to be applied.

To conclude, there is an increase in the knowledge about stunting as an effect of health education through video media among women of childbearing age in the working area of Public Health Center Jatinangor.

\section{References}

1. Hidayat MS, Pinatih GNI. Prevalensi stunting pada balita di wilayah kerja Puskesmas Sidemen Karangasem. E-Jurnal Medika Udayana. 2017;6(7):33416.

2. Ayuningtyas A, Simbolon D, Rizal A. Asupan zat gizi makro dan mikro terhadap kejadian stunting pada balita. Jurnal Kesehatan. 2018;9(3):444-9.

3. WHO. Childhood stunting: challenges and opportunities. Report of a Promoting Healthy Growth and Preventing Childhood Stunting colloquium. Geneva: World Health Organization; 2014.

4. WHO. Guideline: assessing and managing children at primary health-care facilities to prevent overweight and obesity in the context of the double burden of malnutrition: updates for the Integrated Management of Childhood Illness (IMCI). Geneva: World Health Organization; 2017.

5. Haddad L, Achadi E, Bendech MA, Ahuja A, Bhatia K, BhuttaZ, etal. The Global Nutrition Report 2014: actions and accountability to accelerate the world's progress on nutrition. J Nutr. 2015;145(4):663-71.

6. Badan Penelitian dan Pengembangan Kesehatan Kementerian Kesehatan Republik Indonesia. Hasil Utama Riskesdas 2018. Jakarta: Badan Penelitian dan Pengembangan Kesehatan Kementerian Kesehatan Republik Indonesia; 2018.

7. Waroh YK. Pemberian makanan tambahan sebagai upaya penanganan stunting pada balita di Indonesia. EMBRIO. 2019;11(1):47-54.

8. Arsyati AM. Pengaruh penyuluhan media audiovisual dalam pengetahuan pencegahan stunting pada ibu hamil di Desa Cibatok 2 Cibungbulang. Promotor. 2019;2(3):182-90.

9. Rahmandiani RD, Astuti S, Susanti AI, Handayani DS, Didah D. Hubungan pengetahuan ibu balita tentang stunting dengan karakteristik ibu dan sumber informasi di Desa Hegarmanah Kecamatan Jatinangor Kabupaten Sumedang. Jurnal Sistem Kesehatan. 2019;5(2):74-80.

10. Hadisuyitno J, Riyadi BD, Supariasa IDN. Efektivitas penyuluhan terhadap perubahan pengetahuan kadarzi dan PHBS ibu balita di Desa Pulungdowo, Kecamatan Tumpang, Kabupaten Malang. Vidya. 2017;25(1):110-5.

11. Dewi M, Aminah M. Pengaruh edukasi gizi terhadap feeding practice ibu balita stunting usia 6-24 bulan (The effect of nutritional knowledge on feeding practice of mothers having stunting toddler aged 6-24 months). Indonesian Journal of Human Nutrition. 2016;3(1):1-8.

12. Dahodwala M, Geransar R, Babion J, de Grood J, Sargious P. The impact of the use of video-based educational interventions on patient outcomes in hospital settings: A scoping review. Patient Educ Couns.. 2018;101(12):2116-24.

13. Wirawan S, Abdi LK, Sulendri NKS. Penyuluhan dengan media audio visual dan konvensional terhadap pengetahuan ibu anak balita. KEMAS: Jurnal Kesehatan Masyarakat. 2014;10(1):80-7.

14. Nurlaela D, Sari P, Martini N, Wijaya M, Judistiani RTD. Efektivitas pendidikan kesehatan melalui media kartu cinta anak tentang 1000 hari pertama kehidupan dalam meningkatkan pengetahuan pasangan calon pengantin di KUA Kecamatan Jatinangor. JKesV. 2018;3(2):62-8.

15. Astuti S. Upaya promotif untuk meningkatkan pengetahuan ibu balita 
tentang pencegahan stuntingdengan media integrating card di Kecamatan Jatinangor Kabupaten Sumedang. Jurnal Pengabdian Kepada Masyarakat. 2018;2(6):466-9.

16. Ropika AN. Pemahaman dan praktik pencegahan tekanan darah tinggi di Desa Cilayung (Tinjauan antropologis). Umbara. 2018;3(1):14-24.

17. Agritubella SM, Delvira W. Efektifitas poster pola diit 1000 hari pertama kehidupan (HPK) terhadap pengetahuan ibu hamil tentang nutrisi dalam pencegahan stunting di Puskesmas Rambah Kabupaten Rokan Hulu. Jurnal Endurance. 2020;5(1):168-
79.

18. Soekidjo N. Promosi kesehatan dan perilaku kesehatan. Jakarta Rineka Cipta. 2012.

19. Huda M.Pembelajaran berbasis multimedia dan pembelajaran konvensional (Studi komparasi di MTs Al-Muttaqin Plemahan Kediri). Jurnal Penelitian. 2016;10(1):12546.

20. Ornelas IJ, Ho K, Jackson JC, Moo-Young J, Le A, Do HH, et al. Results from a pilot video intervention to increase cervical cancer screening in refugee women. Health Educ Behav. 2018;45(4):559-68. 